\title{
Factors Associated with Decision to Use a Long-Term Intra Uterine Device: A Path Analysis Evidence
}

\author{
Rindra Deviasti'1), Eti Poncorini Pamungkasari²), Bhisma Murti1) \\ 1)Masters Program in Public Health, Universitas Sebelas Maret \\ 2)Department of Public Health, Faculty of Medicine, Universitas Sebelas Maret
}

\begin{abstract}
Background: Intra uterine device (IUD) is a highly effective contraceptive method with a 98-99 percent success rate over five years of IUD use. However, its share of modern method mix is pitifully small, at less than $5 \%$, in 63 countries and only $5 \%-9 \%$ in a further 32 countries. Moreover, IUD's share is declining in many countries. The reasons for this are not well understood, particularly in Mojokerto, East Java, Indonesia, apart from growing popularity of injectables. This study aimed to examine factors associated with decision to use a long-term intra uterine device using a path analysis model.

Subjects and Method: A case control study was conducted at Puskesmas (community health center) Gondang, Mojokerto, East Java, Indonesia, from April to May 2018. A sample of 225 women was selected for this study by fixed disease sampling, comprising 75 IUD users and 150 non-IUD users. The dependent variable was IUD use. The independent variables were age, education, knowledge, attitude, self-efficacy, cultural belief, husband support, and peer support. Data on IUD use were taken from puskesmas Gondang. The data were collected by questionnaire and analyzed by path analysis.

Results: IUD use was directly and positively associated with positive attitude $(b=0.79 ; 95 \% \mathrm{CI}=$ 0.19 to $1.40 ; \mathrm{p}=0.010)$ and low anxiety $(\mathrm{b}=0.76 ; 95 \% \mathrm{CI}=0.16$ to $1.37 ; \mathrm{p}=0.014)$. IUD use was indirectly associated with cultural belief, self efficacy, education, knowledge, husband support, and peer support.

Conclusion: IUD use is directly associated with positive attitude and low anxiety, and is indirectly associated with cultural belief, self efficacy, education, knowledge, husband support, and peer support.
\end{abstract}

Keywords: intra-uterine devise use, biopsychosocial factor, cultural belief, anxiety

\section{Correspondence:}

Rindra Deviasti. Masters Program in Public Health, Universitas Sebelas Maret, Jl. Ir. Sutami No. 36 A, Surakarta 57126, Central Java. Email: widodarigunung@gmail.com.

Mobile: +6281331301065 .

\section{BACKGROUND}

Long term contraceptive method is effective to reduce birth rate, and it can be used in the long term (Mappaware, 2016). The IUD is one of the best and ideal non-hormonal long term contraceptive types because of its very high effectiveness with mild side effects and can be used by almost all women. The effectiveness of the IUD ranged from 0.6-0.8 pregnancies per 100 women in the first year (Saifuddin, 2012) with mild to mild side effects, such as bleeding (menorrhagia or spotting menorrhagia) and more vaginal secretions (Hidayati, 2009). Unlike the female surgical contraceptive method with the smallest failure rate, which is 0.04 pregnancies per 100 women, but its permanent nature cannot be recovered (Saifuddin, 2012). Similarly, contraceptive implants are made from hormonal so it does not close the possibility at the beginning of the acceptor installation that does not have mens- 
truation and irregular bleeding (Hidayati, 2009). Implant contraception also has many contraindications (Kurniawati, 2014).

The Health Profile of the Republic of Indonesia in 2015 showed the IUD acceptors of only $10.73 \%$ (Ministry of Health, 2016). East Java Province has decreased IUD acceptors, i.e. in 2015 (12.94\%) (Ministry of Health, 2016) fell to $12.65 \%$ (Ministry of Health, 2017). Health Profile Data of Mojokerto Regency in 2015 showed that the IUD users were $7.1 \%$ (Mojokerto District Health Office, 2016) increased slightly in 2016 (8.3\%) (Mojokerto District Health Office, 2017). IUD utilization trends in Mojokerto district show an increase in line with increasing age of EFA, but the percentage of users of injectable contraception and pill is still much larger ( $>60 \%)$. Gondang district, Mojokerto has low IUD participants compared to short-term contraceptives (Mojokerto District Health Office, 2017).

East Java Province had high contraceptive prevalence rate (CPR) number and low total fertility rate (TFR). Higher use of hormonal contraceptives (injections and pills) than IUDs is likely to increase TFR (Hartanto, 2016, BKKBN East Java, 2017).

This study aimed to examine factors associated with decision to use a long-term intra uterine device using a path analysis model.

\section{SUBJECTS AND METHOD \\ 1. Study Design \\ This was an analytic observational study with a case-control design. The study was conducted at Gondang community health center, Mojokerto, East Java, Indonesia, from April to May 2018.}

\section{Population and Samples}

The population of the case was all women of IUD acceptors at Gondang community health center, Mojokerto. A sample of 225 women was selected for this study by fixed disease sampling, comprising 75 women with IUD and 150 women without IUD.

\section{Study Variables}

The dependent variable was women decision to use IUD. The independent variables were age, education, knowledge, attitude, self-efficacy, anxiety, cultural belief, husband support, and peer group support.

\section{Operational Definition of Variables}

Age was defined as the study subject's age at the time of study. The data were collected by questionnaire. The measurement scale was continuous, but for the purpose of data analysis, it was transformed into dichotomous, coded o for 20-35 years and 1 for $<20,>35$ years.

Education was defined as the last formal education of the study subjects. The data were collected by questionnaire. The measurement scale was categorical.

Knowledge was defined as the level of knowledge of study subjects about IUDs. The data were collected by questionnaire. The measurement scale was continuous, but for the purpose of data analysis, it was transformed into dichotomous, coded o for low and 1 for high.

Attitude was defined as any positive or negative response given by the study subjects on the IUD use. The data were collected by questionnaire. The measurement scale was continuous, but for the purpose of data analysis, it was transformed into dichotomous, coded $\mathrm{o}$ for negative and 1 for positive.

Self-efficacy was defined as the women's belief about the ability to use IUD. The data were collected by questionnaire. The measurement scale was continuous, but for the purpose of data analysis, it was transformed into dichotomous, coded o for weak and 1 for strong. 
Anxiety was defined as fear or anxiety without a clear cause in the study subjects about the side effects of IUD. The data were collected by questionnaire. The measurement scale was continuous, but for the purpose of data analysis, it was transformed into dichotomous, coded o for low (score $<14$ ) and 1 for high (score $>14$ ).

Culture belief was defined as the women's belief to something believed to be true about IUD use. The data were collected by questionnaire. The measurement scale was continuous, but for the purpose of data analysis, it was transformed into dichotomous, coded $\mathrm{o}$ for negative and 1 for positive.

Husband support was defined as the husband's help on the selection of IUD in terms of information, judgment, instrumental, and emotion. The data were collected by questionnaire. The measurement scale was continuous, but for the purpose of data analysis, it was transformed into dichotomous, coded $\mathrm{o}$ for weak and 1 for strong.

Peer group support was defined as peer's help in IUD selection in terms of information, judgment, instrumental, and emotion. The data were collected by questionnaire. The measurement scale was continuous, but for the purpose of data analysis, it was transformed into dichotomous, coded o for weak and 1 for strong.

The selection of IUD was defined as a selection of non-hormonal and long-term uterine contraceptives to help exclude or limit births. The data were collected by questionnaire. The measurement scale was categorical, coded o for no and 1 for yes.

\section{Data Analysis}

The data were analyzed using path analysis on Stata 13 to examine the relationships between the independent variables to the dependent variables.

\section{Research Ethics}

The research ethics approval was obtained from the Research Ethics Committee of Faculty of Medicine UNS/ Dr. Moewardi hospital, Surakarta, Central Java, Indonesia. The research ethics include informed consent, anonymity, and confidentiality.

\begin{tabular}{|c|c|c|c|}
\hline & RESULTS & & \\
\hline $\begin{array}{l}\text { 1. Sa } \\
\text { Tabl }\end{array}$ & mple Characteristi & risti & \\
\hline No. & Characteristic & $\mathbf{n}$ & $\%$ \\
\hline $\mathbf{1}$ & Age & & \\
\hline & $<20$ years, $>35$ years & 91 & 40.4 \\
\hline & 20-35 years & 134 & 59.6 \\
\hline 2 & Education & & \\
\hline & $<$ senior high school & 107 & 47.6 \\
\hline & $\geq$ senior high school & 118 & 52.4 \\
\hline 3 & Knowledge & & \\
\hline & Low & 134 & 59.6 \\
\hline & High & 91 & 40.4 \\
\hline 4 & Attitude & & \\
\hline & Negative & 118 & 52.4 \\
\hline & Positive & 107 & 47.6 \\
\hline 5 & Self efficacy & & \\
\hline & Low & 123 & 54.7 \\
\hline & High & 102 & $45 \cdot 3$ \\
\hline 6 & Anxiety & & \\
\hline & Anxious & 111 & 49.3 \\
\hline & Not anxious & 114 & 50.7 \\
\hline 7 & Cultural Belief & & \\
\hline & Positive & 126 & 56.0 \\
\hline & Negative & 99 & 44.0 \\
\hline 8 & Husband support & & \\
\hline & Weak & 110 & 48.9 \\
\hline & Strong & 115 & 51.1 \\
\hline 9 & Peer group Support & & \\
\hline & Weak & 127 & 56.4 \\
\hline & Strong & 98 & 43.6 \\
\hline
\end{tabular}

Table 1 shows that as many as 134 women (59.6\%) were at 20-35 years of age. As many as 118 women (52.4\%) had education $\geq$ senior high school. Women who had low knowledge about IUD were 134 (59.6\%). Almost half of women had negative attitude on IUD (118, 52.4\%), low self efficacy (123, 54.7\%), low anxiety (114, $50.7 \%$ ), and positive cultural belief (126, $56.0 \%)$. As many as 115 women (51.1\%) received strong husband support, but as 
many as 127 women (56.4\%) received weak peer group support.

\section{Bivariate Analysis}

Bivariate analysis was used to examine the relationship between age, education, knowledge, attitude, self efficacy, anxiety, cultural belief, husband support, and peer group support with IUD use. The results of bivariate analysis can be seen in Table 2 .

Table 2 shows that women with education $\geq$ senior high school were more likely to use IUD than women with education <senior high school (OR= 85.17; 95\% $\mathrm{CI}=20.03$ to $362.18 ; \mathrm{p}<0.001)$. Decision to use IUD was increased by higher knowledge about IUD $(\mathrm{OR}=2.04 ; 95 \% \mathrm{CI}=1.16$ to 3.59; $\mathrm{p}=0.013)$, positive attitude $(\mathrm{OR}=$ 2.74; $95 \% \mathrm{CI}=1.54$ to $4.87 ; \mathrm{p}<0.001)$, and low anxiety $(\mathrm{OR}=2.69 ; 95 \% \mathrm{CI}=1.51$ to 4.80; $\mathrm{p}=0.001)$.

Decision to use IUD was increased by strong self-efficacy $(\mathrm{OR}=1.38 ; 95 \% \mathrm{CI}=$ 0.79 to $2.41 ; \mathrm{p}=0.256$ ), but it was statistically non-significant. Weak husband support decreased women decision to use IUD $(\mathrm{OR}=0.31 ; 95 \% \mathrm{CI}=0.17$ to 0.55 ; $\mathrm{p}<0.001)$.

Table 2. The results of bivariate analysis

\begin{tabular}{|c|c|c|c|c|c|c|c|}
\hline \multirow{3}{*}{ Independent variables } & \multicolumn{4}{|c|}{ Decision to use IUD } & \multirow{3}{*}{ OR } & \multirow{3}{*}{$95 \% \mathrm{CI}$} & \multirow{3}{*}{$\mathbf{p}$} \\
\hline & \multicolumn{2}{|c|}{ No } & \multicolumn{2}{|c|}{ Yes } & & & \\
\hline & $\mathbf{n}$ & $\%$ & $\mathbf{n}$ & $\%$ & & & \\
\hline \multicolumn{8}{|l|}{ Age } \\
\hline$<20,>35$ years & 39 & 42.9 & 52 & 57.1 & \multirow{3}{*}{0.16} & \multirow{3}{*}{$\begin{array}{c}0.08 \text { to } \\
0.29\end{array}$} & \multirow{3}{*}{$<0.001$} \\
\hline 20-35 years & 111 & 82.8 & 23 & 17.2 & & & \\
\hline Education & & & & & & & \\
\hline$<$ Senior high school & 105 & 98.1 & 2 & 1.9 & \multirow{2}{*}{85.17} & \multirow{2}{*}{$\begin{array}{c}20.03 \text { to } \\
362.18\end{array}$} & \multirow{2}{*}{$<0.001$} \\
\hline $\begin{array}{l}\geq \text { Senior high school } \\
\text { Knowledge }\end{array}$ & 45 & 38.1 & 73 & 61.9 & & & \\
\hline Low & 98 & 73.1 & 36 & 26.9 & \multirow[b]{2}{*}{2.04} & \multirow[b]{2}{*}{1.16 to 3.59} & \multirow[b]{2}{*}{0.013} \\
\hline High & 52 & 57.1 & 39 & 42.9 & & & \\
\hline \multicolumn{8}{|l|}{ Attitude } \\
\hline Negative & 91 & 77.1 & 27 & 36.0 & \multirow[b]{2}{*}{2.74} & \multirow[b]{2}{*}{1.54 to 4.87} & \multirow[b]{2}{*}{$<0.001$} \\
\hline Positive & 59 & 55.1 & 48 & 64.0 & & & \\
\hline \multicolumn{8}{|l|}{ Self efficacy } \\
\hline Weak & 86 & 69.9 & 37 & 30.1 & \multirow{3}{*}{1.38} & \multirow{3}{*}{0.79 to 2.41} & \multirow{3}{*}{0.256} \\
\hline Strong & 64 & 62.7 & 38 & $37 \cdot 3$ & & & \\
\hline Anxiety & & & & & & & \\
\hline High & 86 & 77.5 & 25 & 22.5 & \multirow{2}{*}{2.69} & \multirow{2}{*}{1.51 to 4.80} & \multirow{2}{*}{0.001} \\
\hline Low & 64 & 56.1 & 50 & 43.9 & & & \\
\hline \multicolumn{8}{|l|}{ Cultural belief } \\
\hline Strong & 95 & 75.4 & 31 & 24.6 & \multirow[b]{2}{*}{2.45} & \multirow[b]{2}{*}{1.39 to 4.32} & \\
\hline Weak & 55 & 55.6 & 44 & 44.4 & & & 0.002 \\
\hline Husband Support & & & & & & & \\
\hline Weak & 59 & 53.6 & 51 & 46.4 & & & \\
\hline Strong & 91 & 79.1 & 24 & 20.9 & 0.31 & 0.17 to 0.55 & $<0.001$ \\
\hline Peer group Support & & & & & & & \\
\hline Weak & 78 & 61.4 & 49 & 38.6 & & & \\
\hline Strong & 71 & 73.5 & 26 & 26.5 & 0.58 & 0.32 to 1.02 & 0.057 \\
\hline
\end{tabular}

Figure 1 depicted the structural model of path analysis with parameter estimates. The decision to use IUD was directly affected by attitude and anxiety. It was affected indirectly by knowledge, education, self efficacy, husband support, peer group support, and cultural belief. 


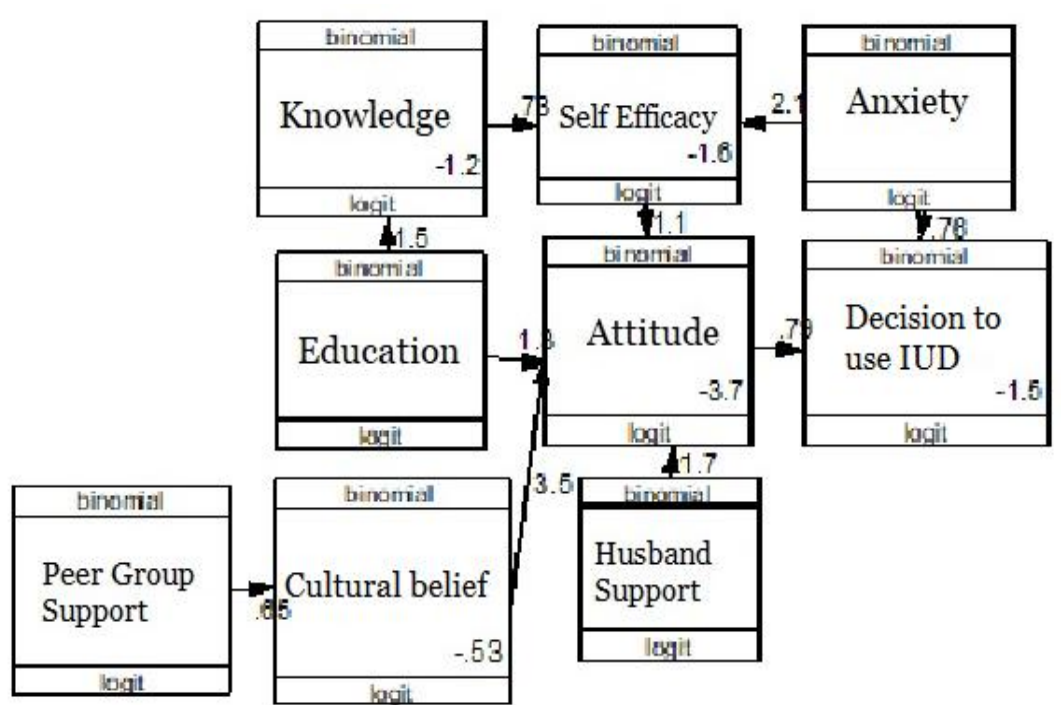

Figure 1. Structural model of path analysis with estimates

Table 3. The results of path analysis on women decision to use IUD

\begin{tabular}{|c|c|c|c|c|c|c|}
\hline \multirow[b]{2}{*}{$\begin{array}{c}\text { Dependent } \\
\text { Variable }\end{array}$} & & \multirow[b]{2}{*}{$\begin{array}{l}\text { Independent } \\
\text { Variable }\end{array}$} & \multirow[b]{2}{*}{ b } & \multicolumn{2}{|c|}{ 95\% CI } & \multirow[b]{2}{*}{$\mathbf{p}$} \\
\hline & & & & $\begin{array}{l}\text { Upper } \\
\text { Limit }\end{array}$ & $\begin{array}{c}\text { Lower } \\
\text { Limit }\end{array}$ & \\
\hline \multicolumn{7}{|l|}{ Direct Effect } \\
\hline Decision to use IUD & $\leftarrow$ & Attitude & 0.79 & 0.19 & 1.40 & 0.010 \\
\hline Decision to use IUD & $\leftarrow$ & Anxiety & 0.76 & 0.16 & 1.37 & 0.014 \\
\hline \multicolumn{7}{|l|}{ Indirect Effect } \\
\hline Attitude & $\leftarrow$ & Cultural belief & $3 \cdot 51$ & 2.64 & $4 \cdot 34$ & $<0.001$ \\
\hline Attitude & $\leftarrow$ & Self efficacy & 1.07 & 0.25 & 1.89 & 0.010 \\
\hline Attitude & $\leftarrow$ & Husband support & 1.67 & 0.82 & 2.52 & $<0.001$ \\
\hline Attitude & $\leftarrow$ & Education & 1.30 & 0.48 & 2.12 & 0.002 \\
\hline Self efficacy & $\leftarrow$ & Anxiety & 2.10 & 1.49 & 2.72 & $<0.001$ \\
\hline Self efficacy & $\leftarrow$ & Knowledge & 0.73 & 0.11 & 1.35 & 0.020 \\
\hline Knowledge & $\leftarrow$ & Education & 1.51 & 0.93 & 2.10 & $<0.001$ \\
\hline Cultural belief & $\leftarrow$ & Peer group support & 0.65 & 0.12 & 1.19 & 0.017 \\
\hline
\end{tabular}

\section{Path Analysis}

Table 3 shows the results of path analysis. Women decision to use IUD was directly and positively affected by positive attitude $(\mathrm{b}=0.79 ; 95 \% \mathrm{CI}=0.19$ to $1.40 ; \mathrm{p}=0.010)$ and low anxiety $(b=0.76 ; 95 \% \mathrm{CI}=0.16$ to 1.37; $\mathrm{p}=0.014)$.

Women decision to use IUD was indirectly and positively affected by knowledge, education, self-efficacy, husband support, peer group support, and cultural belief.

Attitude was positively affected by cultural belief $(b=3.51 ; 95 \% \mathrm{CI}=2.63$ to 4.38; $\mathrm{p}<0.001)$, strong self efficacy $(b=$
1.07; CI $95 \%=0.25$ to $1.89 ; \mathrm{p}=0.010$ ), education $(b=1.30 ; 95 \% \mathrm{CI}=0.48$ to 2.12 ; $\mathrm{p}=0.002)$, and husband support $(\mathrm{b}=1.67$; 95\% CI= 0.82 to $2.52 ; \mathrm{p}<0.001$ ).

Self-efficacy was positively affected by low anxiety $(b=2.10 ; 95 \% \mathrm{CI}=1.49$ to 2.72 ; $\mathrm{p}<0.001)$ and better knowledge $(\mathrm{b}=0.73$; 95\% CI= 0.11 to $1.35 ; \mathrm{p}=0.020$ ).

Knowledge was positively affected by education $(b=1.51 ; 95 \% \mathrm{CI}=0.93$ to 2.10 ; $\mathrm{p}<0.001)$. Positive cultural belief was positively affected by peer group support $(b=0.65 ; 95 \% \mathrm{CI}=0.12$ to $1.19 ; \mathrm{p}=0.017)$. 


\section{DISCUSSION \\ 1. The effect of attitude on women decision to use IUD}

The result of analysis showed that attitude had a direct effect on women decision to use IUD. The result of this study was in line with a study by Builu and Naidoo (2015) which stated that Negative attitudes of study subjects might affect them to not use the IUD. Negative attitudes tend to stay away from, avoid, and dislike the IUD.

Builu and Naidoo (2015) provided a review on various misperception toward IUD. These misperceptions included fear and anxiety about pain in IUD insertion (40\%), fear of getting cancer from IUD (30\%), worry about the negative sexual effect of using IUD (>30\%), and anxiety about uterine perforation (30\%).

\section{The effect of anxiety on women decision to use IUD}

The result of analysis showed that anxiety has a direct effect on women decision to use IUD. The result of this study was in line with Gemzel-Danielsson et al. (2018), which stated that the anxiety about the side effects of IUD might cause the study subjects to not use the IUD as a contraceptive.

A study by Gemzel-Danielsson et al. (2018) showed the anxiety of IUD insertion procedure might increase the level of pain. Anxiety begun with negative experiences of peers or relatives, so even though they heard from sources of information that might be irrelevant, it still contributed to negative perceptions. Anxiety about the side effects of IUD might decrease the interest in IUD selection.

\section{The effect of cultural belief on women decision to use IUD}

The result of analysis showed that cultural belief on IUD has an indirect effect on women decision to use IUD through attitude. The result of this study was in line with a study by Potter et al. (2015). Women who did not use IUD generally held unfavorable belief that IUD could move to the other part of the body, IUD could hurt the user when doing activities or having sex, and pregnancy could still occur even when women used IUD. These beliefs were hold by study subjects who decided not to use IUD.

A study by Potter et al. (2015) found that the belief in rumors or myths related to the IUD was dominated in most of the women including fear of pain, IUD expulsion, foreign objects in the body, and objects that potentially injured the body. Women also believed that IUD expulsion would occur when they have sex or even while bathing, so they would still be exposed to the risk of having an unwanted pregnancy. Women believed that the presence of foreign objects in their bodies would cause inconvenience and could injure their body. They believed that the IUD can cause infertility.

\section{The effect of self efficacy on} women decision to use IUD

The result of analysis showed that self efficacy has an indirect effect on women decision to use IUD through attitude.

The result of this study was in line with a study by Nurani (2017). Generally, people did not try to do anything new unless they think they can do it and it was useful for them. Low self efficacy lead to low women confidence in selecting the IUD.

A study by Nurani (2017) showed that there was a significant correlation between self efficacy and IUD selection on women in reproductive age. Strong self efficacy increased the likelihood of IUD use.

\section{The effect of husband support on women decision to use IUD}

The result of analysis showed that husband support has an indirect effect on women decision to use IUD through attitude. 
The result of this study was in line with a study by Harahap, Santosa and Fitria (2014). The factor of husband support to the use of IUD contraception by mothers of couples in reproductive age showed a positive correlation which mean that the action to use IUD contraceptive device would be done well if they got support from family especially husband (Harahap et al., 2014).

There were four forms of husband support in the use of IUD contraception, including information support in the form of information about IUD that motivated the wives to use IUD, the support of a positive assessment of IUD so that it positively affected wives' perception about IUD, instrumental support in the use of the IUD which indicated the husband's responsibility for any problems encountered with the IUD insertion, such as financing, and emotional support such as not forbidding their wives to have a family planning just because the husband was afraid that his wife had an affair with another man without being caught (Muniroh, Luthviatin and Istiaji, 2014; Rokhmah, 2014; Burns, 2009).

\section{6. the effect of education on women decision to use IUD}

The result of analysis showed that education has an indirect effect on women decision to use IUD through knowledge and attitude.

The result of this study was in line with a study by Tibaijuka et al. (2017) which showed that the higher the educational level of a person, the more likely to choose long ter. This study was supported by Arifiana, Budihastuti and Qadrijati (2018) who stated that education through attitude has an effect on the use of longterm contraception.

Women educational level has an indirect relationship with IUD selection. Education was the basis for a person to gain a better knowledge of contraceptive devices and a positive attitude about contraception. The higher educational level, the higher the possibility of selecting the IUD as a contraceptive method. Higher educational levels have a positive impact on the use of IUD contraception (Asiimwe et al., 2013).

\section{The effect of knowledge about IUD on women decision to use IUD}

The result of analysis showed that knowledge about IUD has an indirect effect on women decision to use IUD through self efficacy.

The result of this study was in line with a study by Nobiling and Drolet (2012) which showed that the lack of knowledge of potential candidate users about IUD was one of the inhibiting factors of IUD use. A study by Gomez et al. (2015) showed that women in reproductive age with sufficient and good knowledge of IUD tend to choose the IUD with the highest probability in those with good knowledge.

\section{The effect of peer group support on women decision to use IUD}

The result of analysis showed that peer group support has an indirect effect on IUD selection through cultural belief. There was indirect association per group support and women decision to use IUD.

The result of this study was in line with a study by Anderson et al. (2015) which found that communication with female friends and family members has a very strong effect in obtaining information about contraception including the IUD. Negative (even usually wrong) information was more commonly acquired and would stick in memory than positive information in this communication model. Women were more likely to hear negative experiences about the IUD from social contact and television. Research on the effect of peers on motivation in using IUD showed that peer group was highly influential in motivating to use IUD (Baihaqi, 2016). 
Journal of Maternal and Child Health (2018), 3(4): 269-277

https://doi.org/10.26911/thejmch.2018.03.04.04

\section{CONFLICT OF INTEREST}

The authors declare that there is no conflict of interest regarding the publication of this article.

\section{REFERENCES}

Anderson N, Steinauer J, Valente T, Koblentz J, Dehlendorf C (2015). Women's social communication about IUDs: a qualitative analysis, 46(3). doi: 10.1363/46e1814.Women.

Arifiana R, Budihastuti UR, Qadrijati I (2018). Biopsychosocial determinants of long-term contraceptive use in women of reproductive age in Surakarta, Central Java. doi: 10.26911/thejhpb.2018.03.01.03.

Asiimwe JB, Ndugga P, Mushomi J (2013). Socio demographic factors associated with contraceptive use among young women in comparison with older women in Uganda. 95. Available at: https://www.dhsprogram.com/pubs/pdf/WP95/WP95.pdf.

Baihaqi AHB (2016). Pengaruh pendidikan kesehatan peer group terhadap motivasi ibu menggunakan kontrasepsi IUD di Dusun Tukharjo, Purwoharjo, Samigaluh, Kulon Progo, Yogyakarta. Available at: http://digilib.unisayogya.ac.id/2014/1/NaskahpublikasiAbda.pdf.

BKKBN Jawa Timur (2017). Evaluasi program KKBPK data Februari 2017.

Builu PM and Naidoo TD. (2015). Attitudes towards and knowledge about intrauterine contraceptive devices among women in the reproductive age group in a resource-constrained setting. SAJOG, 21(2). Available at: https://www.ajol.info/index.php/sajog/articl e/viewFile/129869/119429.

Burns AA (2009). Kesehatan reproduksi perempuan dan metode $\mathrm{KB}$ yang tepat untuk anda. Yogyakarta: Insist Press.
Dinkes Kabupaten Mojokerto (2016). Profil kesehatan Kabupaten Mojokerto tahun 2015. Available at: https://dinkes.mojokertokab.go.id/.../Profil Dinkes Kab. Mojokerto Th.

Dinkes Kabupaten Mojokerto (2017). Profil kesehatan Kabupaten Mojokerto tahun 2016. Available at: https://dinkes.mojokertokab.go.id/.../Profil Dinkes Kab. Mojokerto Th.\%.

Gemzel DK, Fiala AM, Kaunitz LB (2018). Management of pain associated with the insertion of intrauterine contraceptives, 19(4). doi: 10.1093/humupd/dmto22.

Gomez A, Hartofelis EC, Finlayson S (2015). Do IUD knowledge and attitudes predict interest in using an IUD?, Women's Health Issue, 25(4). doi: 10.1016/j.whi.2015.03.011.

Harahap A, Santosa H, Fitria M (2014). Analisis faktor yang mempengaruhi rendahnya pemakaian alat kontrasepsi IUD (intra uterine device) oleh ibu pasangan usia subur di Desa Sabungan Kecamatan Sungai Kanan Kabupaten Labuhanbatu Selatan tahun 2014. Available at: http://download.portalgaruda.org.

Hartanto (2016). Analisis data kependudukan dan KB hasil susenas 2015. Available at: kalbar.bkkbn.go.id.

Hidayati R (2009). Metode dan teknik penggunaan alat kontrasepsi. Jakarta: Salemba Medika.

Kemenkes RI. (2016). Profil kesehatan Indonesia tahun 2015. Available at: www.depkes.go.id/.../profil-kesehatan-indonesia/profil-kesehatan-Indonesia-2015.pdf.

Kemenkes RI (2017). Profil kesehatan indonesia tahun 2016. Available at: www.depkes.go.id/.../Data dan Informasi Kesehatan Profil Kesehatan... 
Kurniawati T (2014). Buku ajar kependudukan dan pelayanan KB. Jakarta: EGC.

Mappaware NA (2016). Pemilihan metode kontrasepsi jangka panjang, IAFKUMI. Available at: http://www.alumnifkumi.org/artikel.html.

Muniroh ID, Luthviatin N, Istiaji E (2014). Dukungan sosial suami terhadap istri untuk menggunakan alat kontrasepsi medis operasi wanita (MOW) (studi kualitatif pada pasangan usia subur unmet need di Kecamatan Puger Kabupaten Jember). Husband's social support on their wive to use contraception, 2(1): 66-71.

Nobiling B, Drolet JC (2012). Exploring trends in intrauterine device ( IUD ) usage among women in the United States: A literature review, 44(2). Available at: https://files.eric.ed.gov/fulltext/EJ997353.pdf.

Nurani DI (2017). Hubungan faktor interpersonal, self efficacy dengan pemilihan kontrasepsi IUD pada wanita pasangan usia subur. Universitas Airlangga. Available at: http://repository.unair.ac.id/62089/.
Potter J, Rubin SE, Sherman P (2015). Fear of intrauterine contraception among adolescents in New York City. 89(5). doi: 10.1016/j.contraception.2014.01.011.Fear.

Rokhmah NA (2014). Perbedaan tingkat kenyamanan dalam melakukan hubungan seksual pada pasangan pengguna kontrasepsi IUD dan Non IUD di Desa Bligo Kecamatan Ngluwar. Available at: http://digilib.unisayogya.ac.id.

Saifuddin AB (2012). Ilmu kebidanan. 4th edn. Jakarta: Yayasan Bina Pustaka Sarwono Prawirohardjo.

Sarafino EP, Smith TW (2014). Health psychology: biopsychosocial interaction. Wiley and Sons.

Tibaijuka L, Odongo R, Welikhe E, Mukisa $\mathrm{W}$, et al. (2017). Factors influencing use of long-acting versus short-acting contraceptive methods among reproductive-age women in a resource-limited setting. BMC Women's Health. doi: 10.1186/s12905-017-0382-2. 